For citation: Stukach V. F., Saparova G. K., Sultanova G. T., Saginova S. A. (2019). Infrastructural Development of Agricultural Production in the Republic of Kazakhstan. Ekonomika Regiona [Economy of Region], 15(1), 561-575 doi 10.17059/2019-2-19

UDC: 338.43 .01

\author{
V. F. Stukach ${ }^{\text {a) }}$, G. K. Saparova ${ }^{\text {b) }}$, G. T. Sultanova ${ }^{\text {c) }}$, S. A. Saginova ${ }^{\text {b) }}$ \\ a) Omsk State Agrarian University (Omsk, Russian Federation) \\ b) Financial Academy (Astana, Kazakhstan e-mail: saniya.saginova@gmail.com) \\ c) JSC "National Agency for Technological Development (Astana, Kazakhstan)
}

\title{
INFRASTRUCTURAL DEVELOPMENT OF AGRICULTURAL PRODUCTS IN THE REPUBLIC OF KAZAKHSTAN
}

This article explores the dependence of the agro-industrial products of the Republic of Kazakhstan on the development level of rural production, social and transport infrastructure. The paper presents main trend of the indices of the agribusiness infrastructural development in the Republic of Kazakhstan according to the time series based on the statistical data of Kazakhstan. The study revealed that the level of endowment in social and industrial infrastructure of agriculture in Kazakhstan remains extremely unstable. This circumstance can consequently form a tendency for a decline and even degradation of the Kazakh villages. As a result, it can lead to a violation and decline of the reproductive processes in the agribusiness, which, in turn, will negatively affect the endowment in products from agricultural raw materials. Hence, the formation and development of the agribusiness infrastructure is seen as an indispensable condition for the effective interaction of the actors of the main and auxiliary production, contributing to the development of general prerequisites for the growth and development of agricultural products. The results of the research can be used by the state in investing social, transport and production development of the village to ensure food security. Agricultural development of rural areas in Kazakhstan based on improving the infrastructure will increase the welfare of rural workers, solve the problem of quality food for the population of the country, and take an active part in the global task of eradicating hunger on the planet.

Keywords: agribusiness, agrarian products, food security, agriculture, infrastructure, gross output, production process, social infrastructure, rural population, investment attractiveness

\section{Introduction}

Public health, living standards and life expectancy are essential features of food security. A significant indicator of food security is the satisfaction of a person's need for adequate nutrition. Moreover, men's working capacity and life expectancy depend on the quality of food. Unfortunately, according to the forecasts of the Food and Agriculture Organization of the United Nations (FAO), the number of people worldwide suffering from chronic malnutrition increased from 2015 to 2016 by $11 \%{ }^{2}$

Food and transport security are also interrelated, since the insufficient development of transport infrastructure can cause loss of crops, damage to food during transportation, violation of delivery terms for producers of pesticides, mineral fertilizers, agricultural machinery,

\footnotetext{
${ }^{1}$ (c) Stukach V. F., Saparova G. K., Sultanova G. T., Saginova S. A. Text. 2019.

${ }^{2}$ The Food and Agriculture Organization of the UN (FAO): official website [Electronic resource]. URL: http://www.fao.org (access date: 15.01.2018).
}

which negatively affects both production and consumption of food.

In the present conditions, the interconnection of agricultural production with the problems of environmental and energy security grows stronger., As the productive forces develop, the production of raw materials, agricultural products and food becomes increasingly dependent on energy resources and environmental factors that change under abriculture's influence. The welfare of the society is ensured by the sustainable development of the social infrastructure, which is attributable to a complex set of factors, such as housing provision, housing improvement, as well as stable food support and maintenance of the optimal state of the natural environment. ${ }^{3}$

The problem of food security is exacerbated by the need to strengthen the protection of consumers' rights and environmental conservation. In this regard, the study conducted by the Economist Intelligence Unit with the financial support of Du Pont is of interest. Based on the results of this

\footnotetext{
${ }^{3}$ Kaygorodtsev A. (2006). Economic and Food Security (questions of theory, methodology and practice: Scientific Monograph / A. Kaygorodtsev. Ust-Kamenogorsk: Media Alliance, 384 p.
} 
study, the country's global food security index has been calculated. The rating scale is from 0 to 100 , where 100 is total security (Table 1 ). ${ }^{1}$

In the world ranking of countries with ensured national food security of 2017, Ireland and the West European countries are leading, while in 2016 the leading place was occupied by the USA. ${ }^{2}$

\section{Theoretical basis}

The countries actively cooperate with the Food and Agriculture Organization of the United Nations (FAO), the World Health Organization (WHO) and their special bodies, such as the Codex Alimentarius (FAO Food Code), where representatives of over 170 states and the European Commission as the representative of the EU work in 30 different committees to elaborate standards, guidelines and codes of industry practice on food quality and safety. ${ }^{3}$

The experience of Canada is also of interest for Kazakhstan. In particular, this is a new fiveyear program adopted by the government (until 2012) and called "Canada's Northern Strategy" [1]. Under the program, the state subsidized food parcel orders for the population living in remote settlements. There are about 135 settlements with a total population of more than 100,000 people. The program was extended to three territories of Canada and covered a number of northern settlements. Given the vast territory of Kazakhstan, the Canadian model could be applied to help the population of remote rural settlements.

In the United States, the regional specialization has become the most important organizational and economic principle for rationalizing the agrarian sector, providing the dynamic development based on high bioclimatic potential and the benefits from innovative achievements [2, 3].

Experience of a range of countries indicates that food self-sufficiency cannot always be achieved even in highly developed countries. For example, in Japan the level of food security is only $50 \%$, but its national companies offer means to import the demanded volumes of food and, being a largest net exporter, to achieve in general the

\footnotetext{
${ }^{1}$ The Global Food Security Index: official website [Electronic resource]. URL: http://foodsecurityindex.eiu.com (access date: 15.01.2018).

2 Global Food Security Index. Humanitarian Encyclopedia [Electronic Resource] // Center for Humanitarian Technologies, 2006-2018 (access date: 03.01.2018). URL: http://gtmarket.ru/ ratings/global-food-security-index/info.

${ }^{3}$ Codex Alimentarius. International Food Standarts (2018). Retrieved from: http://www.fao.org/fao-who-codexalimentarius/home/en/ (date of access: 16.01.2018).
}

Global Food Security Index, 2017

\begin{tabular}{|c|c|c|}
\hline Ranking & Country & Index \\
\hline 1 & Ireland & 85.6 \\
\hline 2 & USA & 84.6 \\
\hline 3 & UK & 84.2 \\
\hline 4 & Singapore & 84.0 \\
\hline 5 & Australia & 83.3 \\
\hline 6 & The Netherlands & 82.8 \\
\hline 7 & Germany & 82.5 \\
\hline 8 & France & 82.3 \\
\hline 9 & Canada & 82.2 \\
\hline 10 & Sweden & 81.7 \\
\hline \multirow[t]{2}{*}{11} & Austria & 81.6 \\
\hline & $\ldots$ & \\
\hline 41 & Russia & 66.2 \\
\hline 43 & Mexico & 65.8 \\
\hline 44 & South Africa & 64.0 \\
\hline 45 & China & 63.7 \\
\hline 46 & Botswana & 63.1 \\
\hline 47 & Egypt & 61.8 \\
\hline 46 & Belarus & 63.0 \\
\hline 47 & Bulgaria & 62.9 \\
\hline 59 & Paraguay & 56.5 \\
\hline \multirow[t]{2}{*}{60} & Kazakhstan & 56.0 \\
\hline & $\ldots$ & \\
\hline 77 & Pakistan & 47.8 \\
\hline 78 & Uzbekistan & 47.5 \\
\hline 79 & Philippines & 47.3 \\
\hline 80 & Myanmar & 44.8 \\
\hline 81 & Nepal & 44.5 \\
\hline 82 & Senegal & 44.2 \\
\hline \multirow[t]{2}{*}{83} & Cambodia & 43.3 \\
\hline & $\ldots$ & \\
\hline 113 & Burundi & 25.1 \\
\hline
\end{tabular}

level of export earnings far exceeding the cost of food imports [4].

Economic security (as an integral part of national security) is the priority of the state policy. In turn, economic security as a systemic formation includes a range of components (food, foreign economic, energy, investment, technological, industrial, transport and communication and other components).

According to Russian scholars, close relationship in ensuring social and economic security means the same that the public security and is an objective social and economic phenomenon that becomes a modulator of scientific and technological progress and a factor in the intensification of production [5].

In the history of forming the food security, international organizations, predominantly the United Nations, play an important role. Under 
the United Nations auspices, the human right to a decent life is officially fixed in the Universal Declaration of Human Rights (1948) and in the International Covenant on Economic, Social and Cultural rights (1966) [6]. In the context of globalization, climate change, global financial crises, there is a threat of a decrease in food consumption, and, hence, the problem of ensuring food security. At the UN summit in 2015, one of 17 mail goals was: "To put an end to hunger, to achieve food security, to improve nutrition and to promote sustainable agriculture". ${ }^{1}$ Based on this goal, FAO developed a concept for sustainability in food and agriculture, which identified five principles: improving the efficiency in the use of resources; conserving, protecting and enhancing natural resources; protecting and improving rural livelihoods, equity and social well-being; enhanced resilience of people, communities and ecosystems to external influences; responsible and effective governance mechanisms. ${ }^{2}$

Any country has certain national interests which include food security, import substitution policy, increasing the incomes of domestic producers, which are increasingly difficult to ensure in the context of growing globalization and strengthening of integration processes. Agroindustrial products are influenced by integration factors both within the country and in a global scale. The sustainable development of agribusiness is the basis for ensuring food security.

Agribusiness of Kazakhstan develops in complex internal macroeconomic conditions due to the influence of external factors, and to the consequences of the economic reforms of the 1990s. For a long time, Kazakhstan had no comprehensive approach to the development of rural areas. The rural development is uniquely focused on agricultural products.

Kazakhstan joined WTO on November 30, 2015. This strengthened the integration processes in the agrarian sector. Since 2015, the interaction among the EAEU countries has increased. In 2016, the directions «On coordination of sales and marketing policy of the Member States of the Eurasian Economic Union for agricultural products and foodstuffs» and a number of other projects were adopted at the interstate level. In these conditions, the problems of harmonization of commitments to the partners in the EAEU and the WTO have become more acute.

\footnotetext{
${ }^{1}$ United Nations (2018). Retrieved from: http:// http://www.un.org (date of access: 15.01.2018).

2 Sustainable Food and Agriculture (2018). Retrieved from: http://www.fao.org/sustainability/en (date of access: 16.01.2018).
}

According to Kazakhstani researchers, due to the WTO accession, Kazakhstan reduced the level of support to its agricultural consumers through the measures of the yellow box and increased financing of the green box measures. ${ }^{3}$

The order "On approval of the rules for subsidizing the cost of laying and growing (including restoration) of perennial plantations of fruit and berry crops and grapes» (No. 4-1/168 of February 27, 2015) abolished subsidies for cheaper cost of fuel-lubricants and reduced cost of material assets in crop production, and subsidies per hectare and public procurement. At the same time, the subsequent order "On the approval of the subsidy rules on reimbursement in terms of costs incurred by the agribusiness subject in investing" (No. 9-3 / 726 of August 7, 2015) was aimed at encouraging private investment, increasing the state support for subsidizing the costs of processing enterprises for the purchase of agricultural products for the deep processing production.

In the EAEU countries, the share of support for agriculture remains relatively stable, but not uniform, as Figure 1 shows.

For 2010-2016, the agrarian market capacity grew 2.5 times, the production grew almost 2 times. However, the volumes of imports continue to exceed the export volumes for many types of basic agricultural products, which negatively affects the problem of food security.

Entering the international markets leads to expansion of production due to strengthening of the interconnection of rural territories. We should agree with the opinion of the scientist P. Robson that the change in scale as a direct consequence of integration is a result of so-called statistical and dynamic factors that allow economic entities to make wide use of the opportunities of a more voluminous market [7].

The absence of a differentiated approach has led to a not enough rational territorial allocation of productive forces and an underdeveloped industrial and social infrastructure of rural areas. This is evidenced by the Rural Areas Development Program, which was developed for the period 2004-2010, and, unfortunately, has not been fully implemented.

The number of settlements with high development potential has increased to 2.610,

\footnotetext{
${ }^{3}$ Developing recommendations on the use of the advantages of integration processes within the EAEC to increase the efficiency of the development of agro-industrial production in Kazakhstan: report on research (interim.): Kazakh Research Institute of agribusiness Economics and Rural Development; adv. A. B. Moldashev, exec.: G. A. Nikitina [and others]. Almaty, (2016). p. 125. \# 0115PK01936. Inv.No. 0216РК00998.
} 


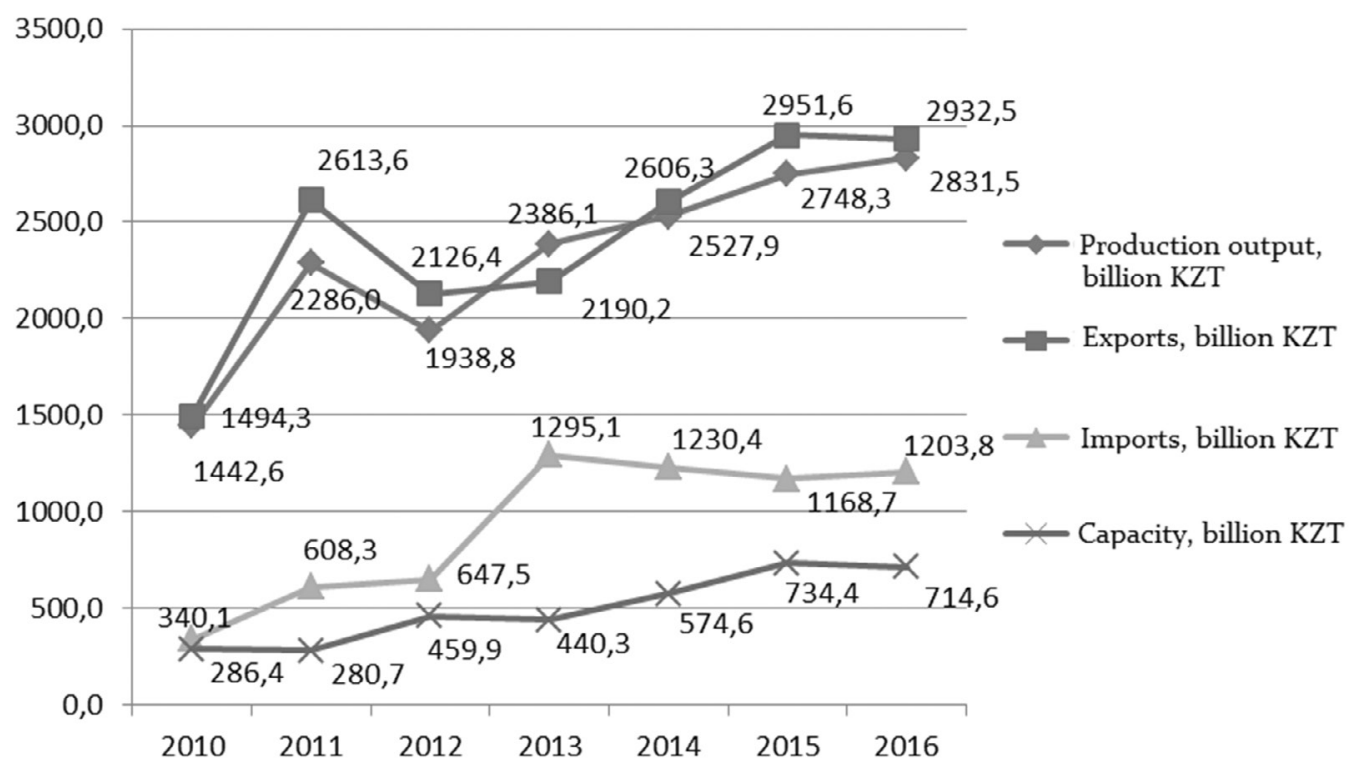

Fig. 1. Dynamics of agrarian products market of Kazakhstan for 2010-2016. Source - Authors' preparation based on the data of the Committee on Statistics of Kazakhstan

Table 2

Dynamics of rural settlements development for 2004-2010

\begin{tabular}{|c|c|c|c|c|}
\hline \multicolumn{2}{|c|}{ Indicators } & 2004 & 2010 & Discrepancy $(+;-)$ \\
\hline \multicolumn{2}{|l|}{ Amount } & 7660 & 6970 & -690 \\
\hline \multicolumn{2}{|l|}{ Population } & 7193.9 & 7520.5 & 326.6 \\
\hline \multirow{2}{*}{$\begin{array}{l}\text { Rural settlement with high } \\
\text { development potential }\end{array}$} & Number of RS & 1062 & 2610 & 1548 \\
\hline & Population, thousand people & 1566.9 & 3909.3 & 2342.4 \\
\hline \multirow{2}{*}{$\begin{array}{l}\text { Rural settlement with average } \\
\text { development potential }\end{array}$} & Number of RS & 5664 & 4258 & -1406 \\
\hline & Population, thousand people & 5329.1 & 3591.7 & -1737.4 \\
\hline \multirow{2}{*}{$\begin{array}{l}\text { Rural settlement with low } \\
\text { development potential }\end{array}$} & Number of RS & 776 & 102 & -674 \\
\hline & Population, thousand people & 288.2 & 19.4 & -268.8 \\
\hline
\end{tabular}

Source: Authors' own preparation based on report of Kazakh Research Institute of agribusiness and rural development.

or 2.5 times compared to 2004; with the average development potential, it decreased by 1.406 , or by $25 \%$; with a low development potential, it decreased by 674 units or 7.6 times, as evidenced by Table 2 .

However, there are doubts about the rate of increase in the number of rural settlements with a high development level due to the predominance of the administrative approach to defining and classifying rural settlements in a particular category in terms of their socio-economic development, as well as about internal migration, a significant outflow of rural population to cities.

Protection of industrial and social infrastructure of rural areas is one of the priorities in recent years. It should be noted that the number of social enterprises has significantly decreased, as evidenced by the statistics evidence suck as a lack of kindergartens, schools, consumer services, and health care institutions.

According to Kazakh scientists, the material and technical base of cultural and leisure facilities remains in a critical position: $34 \%$ of rural settlements have cultural institutions and $42 \%$ have libraries; unsatisfactory condition of roads remains relevant for $70 \%$ of districts; there is a backlog of villages from the city according to the share of housing; lack of engineering development of rural settlements [8].

Foreign scientists highlight the need to structure relations between urban and rural areas, changes in relations to nature, "greening" the economy $[9,10]$.

In modern market conditions, agro-industrial products are basically only a preparatory basis for ensuring the functioning of the processing industry. In this regard, many technological functions performed earlier directly in the agrarian sphere have moved away and interact with the corresponding industrial, trade and service industries and services that act as an infrastructural environment.

As A. Izotov notes, applying to the economy sphere, the infrastructure should be understood as a set of activities and industries that provide its maintenance in order to create the required 
conditions for the full-scale operation of production [11].

Some scholars define social infrastructure as the sphere of society's life, where the required level of well-being is created, which determines the quality of life of the population outside the immediate sphere of production, while others imply the economic relations between society and its members about the consumption of specific goods [12, 13].

One should agree with the opinion of Russian scientists that one of the functions of infrastructure is the creation of general conditions for increasing the efficiency of reproduction, since the infrastructure complex does not create an actual product, but services are the main product of this complex [14].

As for the concept of the agribusiness infrastructure, there is the complexity of its formulation in connection with the fact that agricultural production in a market economy is a kind of raw material appendage for the processing industry, and it actually pushes it out of the system of services and industries that are considered as an infrastructure. However, in our opinion, the infrastructure includes both social and economic conditions that ensure the development of the production process.

We should agree with scientists that the content of the concept "the infrastructure of rural areas" is reflected in specific indicators of the quality of its residents` life, which include the average life expectancy, and the innovative activities of its inhabitants, conditions for recreation, etc. [15].

The economic development of the country's agrarian economy at each level is determined by a certain model of the infrastructure and the specifics of its formation.

The major development of enterprises in the sphere of material services such as wholesale trade, transport, warehousing, gas, electricity, and water supply was observed in the conditions of an extensive period of economic activity in the agribusiness. With regard to the period of intensification of agricultural production, we note that the sharp lag in the development of infrastructure services and industries from the main industries is directly dependent on the nature of the investment policy in the agribusiness. This is reflected in the demand for additional development of construction services, information services, etc. The current period makes such circumstances so at the present stage, in order to overcome the crisis in the agrarian sphere, there is a need for an effective development of the industrial and social infrastructure of the domestic agribusiness, which will create the necessary prerequisites for entry of the agrarian economy of the country in the stage of post-industrial development.

Such infrastructure serving the agribusiness should include enterprises and organizations that will ensure the general conditions for the development of production and livelihoods of people. Infrastructure, as an integral system, is divided into social and production by its intended purpose.

Social and industrial infrastructures as a complex serve for all stages of agro-industrial production. That is why their role is very important in raising the level of the agribusiness efficiency and intensification that is steadily growing.

In the current market conditions, a quantitative and qualitative state of the objects of the agriculture social and industrial infrastructure will play a very important role in the expanded agricultural production. Their use will be accompanied by the external benefits of society, which exceed the marginal private benefits.

Determining the position of the production and social infrastructure in the current system of the country's agricultural mechanism and its relationships with many other elements of the management system, it is necessary to consider existing approaches to the structural formation of the agribusiness as a reproductive and economic system. Proceeding from these preconditions, the forms of influencing the elements of the production and social infrastructure on the reproduction process in the agribusiness will be as follows:

- organizational form of influence in the impact on the level of transaction costs of enterprises and organizations of the regional agro-industrial complex;

- fund-forming form of influence in meeting the needs of all organizations and enterprises of the regional agribusiness in reproduction of fixed funds;

- technological form of influence in modernization of production of construction products and application of innovative technologies;

- integration form of influence in the development of economic interregional relations;

- investment form of influence in direct and indirect investments in the development of social and industrial infrastructure (macro level) and the formation of investment attractiveness of the agribusiness (regional level).

In the Republic of Kazakhstan, there is the problem of poor quality of infrastructure in all its components. This situation is complicated by 
a small inflow of investment, weak interaction between different sectors, a high degree of depreciation of fixed assets and an outdated regulatory system.

At the same time, it should be noted that the infrastructure should potentially be one of the most important competitive advantages for the Kazakhstani regions, especially when taking into account the length of the country.

Some researchers attribute the deterioration of ruralareas to the degradation or underdevelopment of infrastructure. At the same time, they note a number of reasons, focusing on the social or transport infrastructure. Therefore, we believe that the problem of infrastructure support of the territory should be considered as a whole complex of problems.

Population decline, rural degradation and other factors directly depend on the infrastructure (social, production, transport).

In the current period, the share of agricultural organizations in the structure of agricultural production is clearly decreasing. For example, the registered legal entities amounted to 12.989 in 2013 and 12.858 in 2015.

Just in recent years, there has been an increase in this indicator.

The consequences of these circumstances were as follows:

1) in the field of industrial infrastructure

- a large and unsatisfied request for specialists to work at the agricultural enterprises,

- backlog of the level of equipment and technology from foreign competitors,

- replacement of the condition of the production process`s resource base (including fertilizers and pest control agents),

- instability of pricing policy in the market of financial services providers (insurance, loans, etc.), petroleum products, etc.

- constant changes in the structure of owners,

2 ) in the field of social infrastructure

- reduction of health facilities,

- insufficient number of cultural and recreation facilities,

- the difference in the levels of training in the educational institutions of city and village,

- lack of facilities in the service sector (hair salons, etc.),

- a significant difference in the standard of living of urban and rural populations (wages, social security),

- lack of prospects for personal development.

According to the Committee on Statistics of the Ministry of National Economy of Kazakhstan, the number of hospital organizations in 2015 decreased to 901 compared to 2008, when the number of hospital organizations was 1.041.

3 ) in the field of transport infrastructure

- lack (or insufficient quantity/quality) of communications for production organizations,

- lack (or insufficient quantity/quality) of communications for rural residents,

- insufficient routes of public transport means.

Among the problems hampering the development of the agribusiness, there are small-scale production, low animal productivity, underdevelopment of the feed industry, inadequate financing of agricultural enterprises and commodity producers [16].

The diminishing role of the agrarian sector also had a negative impact on the development of rural areas. Ignoring the social laws, the subjective opinion of some leaders that everything depends on the will of people and public institutions led to the fact that cooperation has lost its fundamental principles and is nearing extinction throughout the post-Soviet space at the present stage [17]. Unfortunately, rural workers were not prepared to changes, to creation of a socially-oriented market economy. It is known, farmer cooperation is the more common form of integration, and Sweden, the Netherlands, and Denmark are an example of such "cooperative countries" [18].

The above circumstances can be listed further, and their significance and level of influence on the development of a particular territory depend on many factors such as the degree of remoteness from large settlements, the policies of local and regional authorities.

Let us assess the dependence of agricultural production of the Republic of Kazakhstan on the level of development of rural production, social and transport infrastructure.

For a factor analysis of the interrelation between a number of indicators of the economic (production and transport) and social infrastructure of agriculture and its more complete expression, we will form an adequate system of indicators for the rural production, social and transport infrastructure in Table 3.

\section{Methods and Data}

Specifically for the selected key indicators that determine the infrastructure development of Kazakhstan`s agribusiness, let us examine the hypothesis on the existence of a trend characterizing the long-term basic regularity of the development of the studied phenomenon of the agricultural infrastructure indicators of Kazakhstan. 
Agribusiness Infrastructure Indicators

\begin{tabular}{|c|c|c|}
\hline Effectiveness Indicator & Infrastructure Group & Factor Indicator \\
\hline \multirow{20}{*}{$\begin{array}{l}\text { Gross output of } \\
\text { agricultural products } \\
\text { (services), billion KZT }\end{array}$} & \multirow{12}{*}{ Social } & Economically active population - total, thousand people \\
\hline & & $\begin{array}{l}\text { Economically active population with higher education, thousand } \\
\text { people }\end{array}$ \\
\hline & & $\begin{array}{l}\text { Provision of housing for the population, sq. m. per person - rural } \\
\text { areas }\end{array}$ \\
\hline & & $\begin{array}{l}\text { Average monthly nominal wage of one employee by types of } \\
\text { economic activity, KZT }\end{array}$ \\
\hline & & Number of doctors of all specialties, thousand people \\
\hline & & Number of middle medical personnel, thousand people \\
\hline & & Number of hospital organizations \\
\hline & & Number of hospital beds, thousands \\
\hline & & Housing improvements - water supply, \% \\
\hline & & Housing improvements - sewage system, \% \\
\hline & & Housing improvements - central heating, $\%$ \\
\hline & & Housing improvements - Gas (incl.liquid), \% \\
\hline & \multirow{4}{*}{ Production } & Number of registered legal entities, units \\
\hline & & Number of fixed telephone lines in rural areas, thousand units \\
\hline & & Agrochemistry production, mln KZT \\
\hline & & $\begin{array}{l}\text { Investments in fixed assets by directions of use - Agriculture, } \\
\text { forestry and fisheries, mln. KZT }\end{array}$ \\
\hline & \multirow{4}{*}{ Transport } & $\begin{array}{l}\text { Cargo transportation and turnover by mode of transport - all types } \\
\text { of transport }\end{array}$ \\
\hline & & Cargo transportation and turnover by mode of transport - railway \\
\hline & & Cargo transportation and turnover by mode of transport - auto \\
\hline & & $\begin{array}{l}\text { Investments in fixed assets by directions of use - transport and } \\
\text { warehousing, mln KZT }\end{array}$ \\
\hline
\end{tabular}

Source: Authors' own preparation.

The hypothesis of the interrelation between the frequency of fluctuations in yields, droughts, precipitation, temperature behaviour, natural abnormal phenomena, investment inflow leading to growth or slowing down of business activity in crop growing and livestock breeding is fully justified. To find such a periodicity means to be able to predict the dynamics processes and to be ready for their occurrence. We believe that the cyclicity as a global approach combining the relationship between retrospective and predictive processes contributes to a deeper understanding of economic phenomena. This provision is acceptable in studying the dynamics of the agricultural sector where the idea of multi-cyclicity is reasonably applicable. Contributions to the study of agricultural markets, the role of industrial infrastructure in the economic development were made by scientists of the Institute of Conjuncture, created in Russia in the 1920s. The Institute was headed by the Russian N.D. Kondratiyev, the economist, now considered as a representative of the Russian branch of the institutional and social direction in economic science, the investigator of cyclical waves in the economy.
Studies showed that a long wave of economic crises in agriculture can be divided into two half-waves of 30-year duration, where we can identify upward and downward trends within each of these waves. For 30 years, there have been investment flows leading to an increase or a slowdown in business activity in crop growing and livestock breeding; there can be 2 or 3 shifts. Moreover, within the 11-12-year period, the existence of Kitchin cycles connected with the peculiarities of agricultural production is evident [19].

The pattern of cycle manifestation is relevant due to the boundary delimitation of the specific features of the cyclical dynamics inherent in the agricultural sector of the particular region, especially for such an agricultural country as the Republic of Kazakhstan with its vast territory. An important role is played by the regional specificity such as geographical features of territorial formations within the country, political decisions of government bodies in various fields, etc. All this make impact on the mechanism of their development. Therefore, it is inadvisable to copy the revealed patterns and tendencies of 
the economic dynamics from one region to other territories.

Thus, the use of methods to solve the indicated problem in the development of Kazakhstan's agricultural sector from the viewpoint of presence of cyclical fluctuations subject to the influence of random factors is fully justified.

Levels of the series: the time series is divided into two approximately equal parts in terms of the number of members, each of which is regarded as some independent sample having a normal distribution. If the time series has a trend, then the averages calculated for each complex must significantly differ from each other. If the discrepancy is insignificant, unimportant (random), then the time series has no trend. Thus, the verification of the presence of a trend in the series under investigation reduces to testing the hypothesis on the equality of average two normally distributed complexes [20].

The presence of the main trend in the development indices of the agribusiness infrastructure of Kazakhstan is determined below, based on the time series data, according to the statistical data of the Committee on Statistics of the Ministry of National Economy of Kazakhstan.

For the selected time series, we calculate the mean values and sample variances:

$$
\begin{gathered}
\bar{y}_{1}=\frac{\sum_{i=1}^{n_{1}} x_{i}}{n_{1}}, S_{1}^{2}=\frac{\sum_{i=1}^{n_{1}}\left(x_{i}-\bar{x}\right)^{2}}{n_{1}}, \\
\bar{y}_{2}=\frac{\sum_{j=1}^{n_{2}} x_{j}}{n_{2}}, S_{2}^{2}=\frac{\sum_{j=1}^{n_{2}}\left(x_{j}-\bar{x}\right)^{2}}{n_{2}}, \\
\bar{y}_{1}=1909 ; S_{1}^{2}=122617 ; \bar{y}_{2}=2740 ; S_{2}^{2}=163907 .
\end{gathered}
$$

We check the hypothesis on the equality of dispersion if $\alpha=0,05$.

$$
H_{0}: \sigma_{1}^{2}=\sigma_{2}^{2}, H_{1}: \sigma_{1}^{2} \neq \sigma_{2}^{2} .
$$

The F-distribution serves to answer these questions [21].

$$
F_{\text {calc. }}=\frac{S_{2}^{2} / \sigma_{x}^{2}}{S_{1}^{2} / \sigma_{y}^{2}}=\frac{163907}{122617}=1.336 .
$$

When the general dispersions are equal, the calculated value of the $F$-distribution becomes:

$$
F_{\text {calc. }}=\frac{S_{2}^{2}}{S_{1}^{2}} \approx \frac{163907}{122617}=1.336,
$$

where $\sigma_{x}^{2}$ and $\sigma_{y}^{2}-$ general dispersions of two samples $n_{x}$ and $n_{y^{*}}$.

The $F$-distribution is tabulated.

It is determined by two parameters $v_{1}$ and $v_{2}$ degrees of variance.

$$
\begin{gathered}
v_{1}=n_{x}-1 ; v_{2}=n_{y}-1 . \\
v_{1}=3-1=2 ; v_{2}=3-1=2 . \\
F_{c r}(0.05 ; 2.2)=19.00 .
\end{gathered}
$$

Since $F_{\text {calc. }}<F_{c r}(0.05 ; 2.2)$, there is no reason to reject the null hypothesis. According to observations, the variances of general totality are equal, $\sigma_{1}^{2}=\sigma_{2}^{2}$, the corrected dispersions $\left(S_{1}^{2}\right.$ и $\left.S_{2}^{2}\right)$ differ insignificantly, (the discrepancy between them is accidental). Then we can review the main hypothesis:

$$
\begin{gathered}
H_{0}: \bar{y}_{1}=\bar{y}_{2}, H_{1}: \bar{y}_{1} \neq \bar{y}_{2}, \\
=\frac{\bar{T}_{\text {calc. }}=}{\sqrt{\left(n_{1}-1\right) S_{1}^{2}+\left(n_{2}-1\right) S_{2}^{2}}} \times \\
\approx \frac{\sqrt{\frac{n_{1} n_{2}\left(n_{1}+n_{2}-2\right)}{n_{1}+n_{2}}} \approx}{\sqrt{(3-1) \cdot 122617+(3-1) \cdot 163907}} \times \\
\times \sqrt{\frac{3 \cdot 3 \cdot(3+3-2)}{3+3}} \approx 2.986 .
\end{gathered}
$$

Then we compare $T_{\text {calc. }}$ with the tabulated value ttest $(\alpha, \kappa)-$ the critical point of the Student's distribution.

Where $\kappa=n-2$ degree of variance, $\alpha-$ preset level of significance.

$$
\kappa=6-2=4 ; t_{\text {test }}(0.05 ; 4)=2.78 .
$$

Since $\left|T_{\text {calc. }}\right|>t_{\text {test }}(0.05 ; 4)$, then there is no reason to reject the null hypothesis that the time series has a trend, since the averages calculated for each totality, are varied significantly. Hence we conclude that the trend of the indicator "Gross output of agricultural products (services)" is present.

This confirms the scientific validity of the current hypothesis adopted in this study.

The calculated values of other indicators are given in Table 4.

Results obtained characterize the existence of a general trend in the dynamics of the development of basic indicators of the infrastructure of Kazakhstan`s agribusiness as a whole. In order to reveal the general trend of factors during the analysed time interval, the time series is smoothed. This is due to the fact that, in addition to the influence of the main factors on the level of the calculated index, there are numerous random factors, thereby causing deviation of levels from the trend. The result of this action is formed with the help of a residual random component [22]. 
Development trends of basic indicators of the infrastructure of Kazakhstan`s Agribusiness

\begin{tabular}{|c|c|c|c|c|c|}
\hline \multirow{2}{*}{ Indicator } & $F_{\text {calc. }}$ & \multirow{2}{*}{$\boldsymbol{F}_{\text {test }}$} & $T_{\text {calc. }}$ & \multirow{2}{*}{$T_{-}{ }_{\text {test }}$} & \multirow{2}{*}{ Trend } \\
\hline & $F_{\text {tabl. }}$ & & $T_{\text {tabl. }}$ & & \\
\hline $\begin{array}{l}\text { Gross output of agricultural products (services), } \\
\text { billion KZT }\end{array}$ & $\frac{1.336}{19.00}$ & $F_{\text {calc }}<F_{\text {test }}$ & $\frac{2.98}{2.78}$ & $T_{\text {calc }}>T_{\text {test }}$ & Present \\
\hline $\begin{array}{l}\text { Economically active population - total, thousand } \\
\text { people }\end{array}$ & $\underline{0.971}$ & $F_{\text {calc }}<F_{\text {test }}$ & $\frac{0.23}{2.78}$ & $T_{\text {calc }}<T_{\text {test }}$ & Absent \\
\hline $\begin{array}{l}\text { Economically active population - with higher } \\
\text { education, thousand people }\end{array}$ & $\underline{0.488}$ & $F_{\text {calc }}<F_{\text {test }}$ & $\underline{3.24}$ & $T_{\text {calc }}>T_{\text {test }}$ & Present \\
\hline $\begin{array}{l}\text { Provision of housing for the population, sq. m. per } \\
\text { person - countryside }\end{array}$ & $\frac{1.333}{19.00}$ & $F_{\text {calc }}<F_{\text {test }}$ & $\frac{5.345}{2.78}$ & $T_{\text {calc }}>T_{\text {test }}$ & Present \\
\hline $\begin{array}{l}\text { Average monthly nominal wage of one employee } \\
\text { by types of economic activity, KZT }\end{array}$ & $\underline{4.269}$ & $F_{\text {calc }}<F_{\text {test }}$ & $\frac{4.01}{2.78}$ & $T_{\text {calc }}>T_{\text {test }}$ & Present \\
\hline $\begin{array}{l}\text { Number of doctors of all specialties, thousand } \\
\text { people }\end{array}$ & $\frac{2.930}{19.00}$ & $F_{\text {calc }}<F_{\text {test }}$ & $\underline{5.14}$ & $T_{\text {calc }}>T_{\text {test }}$ & Present \\
\hline $\begin{array}{l}\text { Number of middle medical personnel, thousand } \\
\text { people }\end{array}$ & $\underline{0.143}$ & $F_{\text {calc }}<F_{\text {test }}$ & $\frac{1.28}{2.78}$ & $T_{\text {calc }}<T_{\text {test }}$ & Absent \\
\hline Number of hospital organizations & $\frac{29.289}{19.00}$ & $F_{\text {calc }}>F_{\text {test }}$ & $\frac{2.95}{2.78}$ & $T_{\text {calc }}>T_{\text {test }}$ & Absent \\
\hline Number of hospital beds, thousand & $\underline{0.628}$ & $F_{\text {calc }}<F_{\text {test }}$ & $\frac{6.99}{2.78}$ & $T_{\text {calc }}>T_{\text {test }}$ & Present \\
\hline Housing improvement — water supply, \% & $\frac{0.011}{19.00}$ & $F_{\text {calc }}<F_{\text {test }}$ & $\frac{7.56}{2.78}$ & $T_{\text {calc }}>T_{\text {test }}$ & Present \\
\hline Housing improvement - sewage system, \% & $\underline{0.490}$ & $F_{\text {calc }}<F_{\text {test }}$ & $\frac{8.69}{2.78}$ & $T_{\text {calc }}>T_{\text {test }}$ & Present \\
\hline Housing improvement — central heating, \% & $\underline{0.231}$ & $F_{\text {calc }}<F_{\text {test }}$ & $\frac{1.23}{2.78}$ & $T_{\text {calc }}<T_{\text {test }}$ & Absent \\
\hline Housing improvement — gas (incl.liquid), \% & $\frac{0.016}{19.00}$ & $F_{\text {calc }}<F_{\text {test }}$ & $\frac{9.69}{2.78}$ & $T_{\text {calc }}>T_{\text {test }}$ & Present \\
\hline Number of registered legal entities, units & $\frac{5.154}{19.00}$ & $F_{\text {calc }}<F_{\text {test }}$ & $\underline{5.68}$ & $T_{\text {calc }}>T_{\text {test }}$ & Present \\
\hline $\begin{array}{l}\text { Number of fixed telephone lines in rural areas, } \\
\text { thousand units }\end{array}$ & $\frac{2.807}{19.00}$ & $F_{\text {calc }}<F_{\text {test }}$ & $\frac{0.41}{2.78}$ & $T_{\text {calc }}<T_{\text {test }}$ & Absent \\
\hline Agrochemistry production, mln KZT & $\frac{5.837}{19.00}$ & $F_{\text {calc }}<F_{\text {test }}$ & $\underline{5.76}$ & $T_{\text {calc }}>T_{\text {test }}$ & Present \\
\hline $\begin{array}{l}\text { Investments in fixed assets by directions of use - } \\
\text { Agriculture, forestry and fisheries, mln KZT }\end{array}$ & $\underline{0.867}$ & $F_{\text {calc }}<F_{\text {test }}$ & $\frac{4.36}{2.78}$ & $T_{\text {calc }}>T_{\text {test }}$ & Present \\
\hline $\begin{array}{l}\text { Cargo transportation and turnover by types of } \\
\text { transport - all types of transport }\end{array}$ & $\frac{9.430}{19.00}$ & $F_{\text {calc }}<F_{\text {test }}$ & $\frac{4.70}{2.78}$ & $T_{c a l c}>T_{t e s t}$ & Present \\
\hline $\begin{array}{l}\text { Cargo transportation and turnover by types of } \\
\text { transport - railway }\end{array}$ & $\frac{13.012}{19.00}$ & $F_{\text {calc }}<F_{\text {test }}$ & $\frac{5.97}{2.78}$ & $T_{\text {calc }}>T_{\text {test }}$ & Present \\
\hline $\begin{array}{l}\text { Cargo transportation and turnover by types of } \\
\text { transport - auto }\end{array}$ & $\frac{16.135}{19.00}$ & $F_{\text {calc }}<F_{\text {test }}$ & $\frac{5.88}{2.78}$ & $T_{\text {calc }}>T_{\text {test }}$ & Present \\
\hline $\begin{array}{l}\text { Investments in fixed assets by directions of use - } \\
\text { Transport and warehousing, mln KZT }\end{array}$ & $\underline{3.880}$ & $F_{\text {calc }}<F_{\text {test }}$ & $\frac{4.17}{2.78}$ & $T_{\text {calc }}>T_{\text {test }}$ & Present \\
\hline
\end{tabular}

Source: Authors' own preparation based on statistical data for Kazakhstan.

The factor analysis of the interrelation between a number of indicators of the infrastructure of the economic (production and transport) and social development of agriculture shows a definite relationship between the social, production and transport processes in the agrarian sphere (Table 5).

\section{Results and Discussion}

The results of the factor analysis show a fairly close relationship between the levels of the economically active population, those with higher education, provision of the population with housing in rural areas, number of doctors of all specialties, number of hospital organizations and number of hospital beds. A significant level 
Table 5

Determining connection between the factors of the infrastructure of economic (industrial, transport) and social development of agriculture

\begin{tabular}{|c|c|}
\hline \multicolumn{2}{|c|}{ Result-based feature (Gross output of agricultural products (services), billion KZT) } \\
\hline Dependence & factor-based feature \\
\hline $\begin{array}{c}\text { Pair correlation coefficient }(R)=0.59 \\
\text { Determination coefficient }\left(R^{2}\right)=0.35 \\
\text { Elasticity coefficient }(E)=1.26\end{array}$ & Economically active population - total, thousand people \\
\hline $\begin{array}{c}\text { Pair correlation coefficient }(R)=0.91 \\
\text { Determination coefficient }\left(R^{2}\right)=0.82 \\
\text { Elasticity coefficient }(E)=9.33\end{array}$ & $\begin{array}{l}\text { Economically active population - with higher education, thousand } \\
\text { people }\end{array}$ \\
\hline $\begin{array}{c}\text { Pair correlation coefficient }(R)=0.74 \\
\text { Determination coefficient }\left(R^{2}\right)=0.56 \\
\text { Elasticity coefficient }(E)=1.41\end{array}$ & $\begin{array}{l}\text { Provision of housing for the population, sq. m. per person } \\
- \text { countryside }\end{array}$ \\
\hline $\begin{array}{c}\text { Pair correlation coefficient }(R)=0.16 \\
\text { Determination coefficient }\left(R^{2}\right)=0.03 \\
\text { Elasticity coefficient }(E)=1.06\end{array}$ & $\begin{array}{l}\text { Average monthly nominal wage of one employee by types of economic } \\
\text { activity, KZT }\end{array}$ \\
\hline $\begin{array}{c}\text { Pair correlation coefficient }(R)=0.77 \\
\text { Determination coefficient }\left(R^{2}\right)=0.59 \\
\text { Elasticity coefficient }(E)=9.33\end{array}$ & Number of doctors of all specialties, thousand people \\
\hline $\begin{array}{c}\text { Pair correlation coefficient }(R)=0.26 \\
\text { Determination coefficient }\left(R^{2}\right)=0.07 \\
\text { Elasticity coefficient }(E)=3.19\end{array}$ & Number of middle medical personnel, thousand people \\
\hline $\begin{array}{c}\text { Pair correlation coefficient }(R)=0.78 \\
\text { Determination coefficient }\left(R^{2}\right)=0.62 \\
\text { Elasticity coefficient }(E)=1.79\end{array}$ & Number of hospital organizations \\
\hline $\begin{array}{c}\text { Pair correlation coefficient }(R)=0.75 \\
\text { Determination coefficient }\left(R^{2}\right)=0.56 \\
\text { Elasticity coefficient }(E)=2.91\end{array}$ & Number of hospital beds, thousand \\
\hline $\begin{array}{c}\text { Pair correlation coefficient }(R)=0.57 \\
\text { Determination coefficient }\left(R^{2}\right)=0.34 \\
\text { Elasticity coefficient }(E)=2.62\end{array}$ & Housing improvement - water supply, \% \\
\hline $\begin{array}{c}\text { Pair correlation coefficient }(R)=0.69 \\
\text { Determination coefficient }\left(R^{2}\right)=0.49 \\
\text { Elasticity coefficient }(E)=0.36\end{array}$ & Housing improvement - sewage system, \% \\
\hline $\begin{array}{c}\text { Pair correlation coefficient }(R)=0.76 \\
\text { Determination coefficient }\left(R^{2}\right)=0.58 \\
\text { Elasticity coefficient }(E)=1.77\end{array}$ & Housing improvement - central heating, \% \\
\hline $\begin{array}{c}\text { Pair correlation coefficient }(R)=0.64 \\
\text { Determination coefficient }\left(R^{2}\right)=0.42 \\
\text { Elasticity coefficient }(E)=13.81\end{array}$ & Housing improvement - gas (incl.liquid), \% \\
\hline $\begin{array}{l}\text { Pair correlation coefficient }(R)=0.41 \\
\text { Determination coefficient }\left(R^{2}\right)=0.16 \\
\text { Elasticity coefficient }(E)=4.45\end{array}$ & Number of registered legal entities, units \\
\hline $\begin{array}{c}\text { Pair correlation coefficient }(R)=0.12 \\
\text { Determination coefficient }\left(R^{2}\right)=0.02 \\
\text { Elasticity coefficient }(E)=4.23\end{array}$ & Number of fixed telephone lines in rural areas, thousand units \\
\hline $\begin{array}{c}\text { Pair correlation coefficient }(R)=0.79 \\
\text { Determination coefficient }\left(R^{2}\right)=0.63 \\
\text { Elasticity coefficient }(E)=0.16\end{array}$ & Agrochemistry production, mln KZT \\
\hline $\begin{array}{c}\text { Pair correlation coefficient }(R)=0.15 \\
\text { Determination coefficient }\left(R^{2}\right)=0.07 \\
\text { Elasticity coefficient }(E)=1.01\end{array}$ & $\begin{array}{l}\text { Investments in fixed assets by directions of use - Agriculture, forestry } \\
\text { and fisheries, mln KZT }\end{array}$ \\
\hline $\begin{array}{c}\text { Pair correlation coefficient }(R)=0.76 \\
\text { Determination coefficient }\left(R^{2}\right)=0.58 \\
\text { Elasticity coefficient }(E)=3.12\end{array}$ & $\begin{array}{l}\text { Cargo transportation and turnover by types of transport - all types of } \\
\text { transport }\end{array}$ \\
\hline
\end{tabular}


The end of Table 5

\begin{tabular}{|c|l|}
\hline \multicolumn{2}{|c|}{ Result-based feature (Gross output of agricultural products (services), billion KZT) } \\
\hline Dependence & \multicolumn{1}{c|}{ factor-based feature } \\
\hline $\begin{array}{c}\text { Pair correlation coefficient }(R)=0.62 \\
\text { Determination coefficient }\left(R^{2}\right)=0.38 \\
\text { Elasticity coefficient }(E)=0.48\end{array}$ & Cargo transportation and turnover by types of transport - railway \\
\hline $\begin{array}{c}\text { Pair correlation coefficient }(R)=0.85 \\
\text { Determination coefficient }\left(R^{2}\right)=0.73 \\
\text { Elasticity coefficient }(E)=3.49\end{array}$ & Cargo transportation and turnover by types of transport - auto \\
\hline $\begin{array}{c}\text { Pair correlation coefficient }(R)=0.16 \\
\text { Determination coefficient }\left(R^{2}\right)=0.03 \\
\text { Elasticity coefficient }(E)=1.02\end{array}$ & $\begin{array}{l}\text { Investments in fixed assets by directions of use - Transport and } \\
\text { warehousing, mln KZT }\end{array}$ \\
\hline
\end{tabular}

Source: Authors' own preparation based on statistical data for Kazakhstan.

has been achieved in improving the housing stock with the availability of water, gas and central heating, sewerage, as well as the indicators of agrochemical production, transportation of goods and freight turnover by mode of transport (road, rail).

As a resulting indicator we took "Gross output of agricultural products (services), billion KZT".

Between the factor-based indicator "Economically active population - total, thousand people" and the calculated result-based indicator, there is both a connection and influence, with the coefficient of determination of 0.35 and the value of the coefficient of pair correlation of 0.59 . The coefficient of elasticity shows that the resultbased indicator will increase by an average of $1.26 \%$ when the factor-based indicator changes by $1 \%$.

A very close relationship is observed between the result-based and factor-based indicators - the area of rural living quarters, with sewage, water, gas and central heating. The calculated coefficients of pair correlation were $0.69,0.57,0.64$ and 0.76 respectively. Estimated result on the factor-based indicator "Cargo transportation and turnover by mode of transport - motor transport" showed the value of the coefficient of pair correlation is equal to 0.85 which indicates a very high interaction with the result-based factor.

The value of the pair correlation coefficient by factor-based feature "Provision of housing, sq. m. per person - the countryside" was 0.74 , and the coefficient of determination was 0.56 , which indicates a fairly strong connection with the result-based factor. Thus, with an increase in the factor of housing provision by $1 \%$, the indicator "Gross output of agricultural products (services)" gives an increase of $1.41 \%$.

Thus, the analysis shows that the change in the factors of the economic bloc is reflected in the values of the social bloc factors.
The analysis of the dependence of the factor "Gross output of agricultural products (services)" on the indicator describing the health care system through the factor "Number of hospital organizations", by means of multiple correlation gave the coefficient of determination equal to 0.62 . This figure indicates that there is a direct relationship between the factors being evaluated, i.e. $62 \%$ of the change in the result-based indicator depends on this factor.

The dependence of the average annual production of agricultural products per one rural resident on the indicators that characterize the education system is further evaluated according to the same algorithm.

The resulting coefficient of determination $\left(R^{2}=0.82\right)$ indicates that there is a direct and close relationship between the selected factors characterizing the impact on the agribusiness development of the higher education system, and $82 \%$ of the change in the result-based indicator depends on this factor.

The results of multiple correlations showed the dependence of the factor "Gross output of agricultural products (services)" on indicators characterizing the education and health system: increase in the level of education of the economically active population, coverage with educational services and increase in the capacity of medical outpatient and polyclinic organizations will lead to an increase in the gross output of agricultural products (services) for the level of the calculated elasticity coefficient of 9.33 and 1.79 respectively.

Calculations show that raising the level of education significantly affects the quality of human capital - the main factor in multiplying the wealth of society, which determines the growth of social productivity. The level of education characterizes the accumulated educational, scientific, labor, creative and intellectual potential that makes up the pool of cumulative knowledge and skills - 
the "spiritual wealth" of society. This quality is transmitted from generation to generation and thus represents an important prerequisite for both the development of the person himself and the growth of the effectiveness of the reproduction process as a whole.

Based on the data on the costs and the number of years of education provided by the state, family, organizations and enterprises, it is possible to track the accumulated potential of knowledge for a certain time period. This circumstance will fully apply to the cultural level of society, i.e. the higher the spiritual development of a person, the more qualitative and rich the person's life is. For this purpose, in order to identify the qualitative characteristics of indicators of the spiritual development of society, indicators that reflect the degree of education and cultural development of society are proposed.

To determine the characteristics of satisfaction of social needs, it is proposed to use both the indicators available to date and the addition of new ones.

Thus, to characterize working conditions it is suggested to use indicators such as the number of people injured at work and the number of people injured at work with a fatal outcome (per 10,000 people working). Characterization of the conditions of rest is proposed to be assessed with two quantitative indicators: the number of Kazakhstanis who have rested in the estimated period and one indirect indicator that characterizes the tourist attractiveness of Kazakhstan.

Thus, it is obvious that there is a direct quantitative relationship between the level of development of the social infrastructure of rural areas and the results of agricultural production.

The development of social infrastructure determines the level of comfort for the population residing in the territory of the region, provides social stability, promotes the consolidation of the population, the inflow of entrepreneurial structures, determine the level of the territorial competitiveness. This corresponds to the modern view of M. Porter's competitiveness.

The performed research provides an opportunity to assess the level of development of the infrastructure of municipal rural areas through the integrated complex factors, to identify the necessary growth points for targeted impact on performance indicators: improvement of population conditions and growth of agricultural production.

Development and practical application of research tools provide the opportunity to manage social processes. Based on the analysis of empirical materials, the substantive part of the interrelation between agricultural production and social infrastructure has been determined. It was established that there is a direct correlation between the level of the social infrastructure development in rural areas and agricultural production. The results of the analysis showed that the social infrastructure facilities in the region are disproportionately dispersed in the municipal districts. General trends in the development of the economy and the social sphere of the Republic of Kazakhstan are characterized as consistently positive.

The performed studies on the mutual influence of the social infrastructure of the village and directly on agricultural production made it possible to identify a number of problems and to determine the directions of work on their solution; such directions are as follows: to develop the social infrastructure serving the population households, since this sector produces about 52$54 \%$ of all production in the country; to develop the infrastructure of a territorial micro-cluster; to establish the interaction between the entities of the territory of a particular rural settlement or a municipal district; to establish the infrastructure of public-private partnership in personnel training and ensuring the population employment. This is especially important in coordinating the actions of government bodies, educational institutions, consumers and sellers in the labor market. To develop the infrastructure ensuring the adaptation of young people to the agricultural labour market and the prevention of young people outflow; in the region there is a need for creation of servicing agricultural consumer cooperatives due to the fact that the existing infrastructure does not meet the needs of private subsidiary farms in operation servicing.

When working as part of a cooperative of citizens who run a subsidiary farm, the costs for cultivating land and fodder conservation will be reduced by $20 \%$; the development of relations between the households of the population and market institutions within the framework of a food microcluster will increase the agricultural producer's share in the final product price from 35 up to 60$70 \%$ and the share of domestic food products in the market up to $70 \%$ due to the development of the sales system; increase the production cost up to $40 \%$ when it is sold off-season with the creation of its own transport and storage network; reduce transaction costs to $30 \%$, expanding the network of information and consulting services and access to Internet resources. To ensure revenue growth up to $20 \%$ with the establishment of independent 
organizations engaged in determining the quality of agricultural products.

When creating an operating mechanism for public-private partnerships, the following results can be obtained: coordination of efforts in development of the regional labour market and improvement of the adaptation processes thereon; provision of private-state partnership in the field of training of highly qualified and highly demanded personnel for the agribusiness; information support for participants in the partnership; creation of an innovative educational infrastructure in favour of educational institutions of various levels in agricultural training profile. The need for provision of the country's food security in the context of Kazakhstan's accession to the WTO puts forward the creation and the development of social infrastructure institutions in the food market system of the metropolis as a priority. The creation of a coordinating structure in the departments of economic policy in the metropolises administration will allow weakening the contradiction of economic interests of trade networks, raw material processors, and agricultural producers in the region. This can be achieved by concluding agreements when using the capacities of the commodity distribution infrastructure of trade networks and wholesale and retail trade capacities available in the regions. Thus, methodological and practical recommendations are in demand for the region.

It follows from the analysis that the change in factors of the economic bloc is reflected in the social bloc factor values.

\section{Conclusion}

The results of the analysis showed that, to a large extent, the social infrastructure location is not integrated in the territory of the country . In this regard, there is a stratification of the social well-being of rural areas and the villagers living there. The most developed and evenly developing areas are those adjacent to large cities and regional centres.

In general, common trends in the development of the economy and the social sphere of the country's agricultural sector can be characterized as positive, but there is still no sustainable level of development of social, food, transport infrastructure, which affects the quality of life of the population in rural areas.

The study revealed that, at present, the level of provision of Kazakhstan's agriculture with the objects of social and industrial infrastructure remains in an extremely unstable state, which can form a trend for the decline and degradation of the Kazakh village, and, as a result, lead to the disruption and the decline of reproductive processes in agribusiness. Therefore, the creation and the development of infrastructure is seen as a prerequisite for effective interaction between the actors of the main and auxiliary industries, ensuring the creation of common preconditions for the development and the growth of agroindustrial products, which in turn will contribute to solving food security problems.

All this explains the need for state participation in investment support for social, production and transport development of the villages, In modern conditions, this support should be aimed not so much at increasing individual quantitative indices of agricultural production, but also at the ability of the agrarian sector to expand reproduction, to achieve better satisfaction of social needs and quality of life of the rural population as a whole, preservation and augmentation of infrastructure.

In modern conditions, for the solution of the above tasks, it is necessary to point out the importance of strategic management. Discussions on the problems of strategic adaptation of organizations have been held for a long time, especially for non-profit organizations that are characterized by a low degree of influence on the leadership changes, ignoring strategic changes [23].

The further development of the infrastructure depends on the improvement of state policy in the countryside and on the development of modern strategies of the agricultural cooperative organizations, the revival of the entrepreneurial spirit in the countryside in the context of globalization and the internationalization of economic processes [24].

An important step is the entry of agricultural enterprises into international markets, which increases the importance of the work of economic security services, which in turn is due to the availability of qualified personnel, computer systems for working with databases, etc. According to American researchers, the economic security service at the enterprise passes certain stages [25].

Among equally important tasks, there is identification of technologies critical for the country. These technologies are the forces of national economic development and security [26]. The low share of innovations, the lack of mechanisms to stimulate their development and implementation hinder the development of the agricultural sector, lead to a backlog of world scientific and technological progress, and exacerbate destructive trends in production and consumption [27]. 
Improving the efficiency of the food market, and therefore solving the problems of ensuring food security depend on the development of both the social and industrial infrastructure of rural areas, and thus the accelerated introduction of innovative technologies. In turn, the increase in business activity of organizations including agrarian ones depends on the development of the institutional structure of the regional agro-food market, as this leads to a reduction in transaction costs [28]. According to J. Wallis and D. Nort, the share of the transactional sector in the US grew from $26 \%$ of GNP in 1870 to $55 \%$ of GNP in 1970 , but transaction costs per unit of national product decreased particularly because of the outstripping growth of the state transaction sector [29].

The development of the infrastructure of rural areas will be facilitated by improved institutions of ownership of land for agricultural purposes, the contract system and the development of the institution of competition.

Improving the infrastructure will contribute to the recovery of the agricultural sector, which is especially important for domestic food market stabilization and food security which are the most important conditions for the sustainable development of the entire economy of Kazakhstan.

\section{References}

1. Strokov S. N. (2014). Mekhanizmy Obespecheniia Vnutrennei Prodovol"stvennoi Bezopasnosti Kanady. [Mechanisms for ensuring domestic food security in Canada?] Nikonovskiye chteniya. Teoretiko-metodologicheskie izmereniia, prognozirovaniia i upravleniia prodovol'stvennoi bezopasnost'iu Rossii [Readings from Nikonov. Theoretical and methodological dimensions, forecasting and management of the food security of Russia], 19, 331-332. (In Russ.)

2. Sazonov S. P. (2011). K voprosu o gosudarstvenno-chastnom partnerstve [On Public-Private Partnership], Izvestia VSTU, 14, 19-21. (In Russ.)

3. Altukhov A. (2015). Territorial"no-otraslevoe razdelenie truda v agropromyshlennom proizvodstve rossii — kak osnovnoi faktor ego razvitiia [Territorial and sectoral division of labour in agro-industrial production], Nikonovskiye chteniya. Agrarnaia politika sovremennoi Rossii: nauchno-metodicheskie aspekty i strategiia realizatsii [Readings from Nikonov. Agrarian Policy of Modern Russia: scientific and methodological aspects and development strategy], 7, pp. 9-20. (In Russ.)

4. Anfinogentova A. (2014). Mezhotraslevoi podkhod k obosnovaniiu natsional'noi programmy prodovol'stvennoi bezopasnosti [Cross-sectoral approach to the rationale for the national food security program]. The Economist, 8, 40-47. (In Russ.)

5. Senchagov V. K. (2005). Ekonomicheskaia bezopasnost' Rossii [Economic Security of Russia], General Course: Textbook. 2nd Ed. Moscow, 896. (In Russ.)

6. Dronov R.R. (2001). Podkhody k obespecheniiu ekonomicheskoi bezopasnosti [Approaches to Ensure Economic Security], The Economist, 2, 42-45. (In Russ.)

7. Moldashev A. B., Nikitina G. A. (2017). Napravleniia optimizatsii vzaimodeistviia kazakhstana so stranami eaes $\mathrm{v}$ oblasti agropromyshlennoi politiki [Directions of optimization of interaction of Kazakhstan with the EAEC countries in the field of agri-industrial policy], Problemy agrorynka [Problems of the agromarket], 1, 7-14. (In Russ.)

8. Avdugaliyev R. A. (2008). Ways to improve social infrastructure in rural areas, Collective food security of the CIS countries: problems and solutions, conference proceedings. Almaty: Research Institute of Agriculture Economics and Rural Development, JSC KazAgroInnovation, 481.

9. Ulied A., Biosca O., Rodrigo R. (2010) Urban and Rural Narratives and Spatial Development Trends in Europe: The State of the Question. Barcelona: Mcrit SL, 102.

10. Bino O. (2013) The Green Economy and Sustainable Development: An Uneasy Balance? Environment and Planning C: Government and Policy, 31, 1042. doi: 10.1068/c1310j.

11. Izotov A. S. (1997). Sotsial'naia infrastruktura kak instrument povysheniia effektivnosti predpriiatiia [Social infrastructure as a tool to improve productivity of enterprises]. Cand. Sci. thesis. Saint Petersburg, 203. (In Russ.)

12. Ovchintseva L. A., Merzlov F. V., Popova O. A. (2012). Regional'nyi opyt razrabotki programm ustoichivogo razvitiia sel'skikh territorii [Regional experience in developing programs for sustainable development of rural areas]. Moscow, FSBSI Rosinformagrotech Publ., 112. (In Russ.)

13. Klimushkina Y. S. (2006). Razvitie sotsial'no-proizvodstvennoi infrastruktury sela: na primere Ul'ianovskoi oblasti [Development of the social and industrial infrastructure of the village (on the example of the Ulyanovsk Region)]. Cand. Sci. thesis, Orenburg, 256. (In Russ.)

14. Zhuravel N. M. (1990). Statisticheskoe modelirovanie i prognozirovanie [Statistical modelling and forecasting]. Ed., Granberg A. G., Moscow: Finance and Statistics, 383. (In Russ.)

15. Zekin V. N., Svetlakov A.G. (2014). Prognoznyj scenarij razvitija infrastruktury sel'skih territorij [Forecast scenario of rural infrastructure development (on the example of the Privolzhsky Federal District)]. Ekonomika regiona [Economy of the region], 2, 230-238. (In Russ.)

16. Omarkhanova Zh., Kuznetsova A. R., Salzhanova Z. A., Gimranova G. I., Nakipova G. E. (2015). Ekonomicheskii Mekhanizm Razvitiia APK v Kazakhstane [The economic mechanism of agribusiness development in Kazakhstan], Kazakhstan: Karaganda Economic University Kazpotrebsoyuz, 312. (In Russ.) 
17. Saparova G. K. (2002). Sotsial'no-ekonomicheskie problemy razvitiia potrebitel'skoi kooperatsii Kazakhstana [Socioeconomic problems of consumer cooperation development in modern conditions], Almaty: Gylym, 204. (In Russ.)

18. Serova E. V. (1999). Agrarnaia ekonomika [Agrarian economy], Moscow: State University Higher School of Economics, 479. (In Russ.)

19. Stukach V. F. (2012). Regional'naia Infrastruktura APK [Regional infrastructure of the agribusiness]. Moscow: KolosS, 220 (In Russ.)

20. Nordhaus V., Samuelson L. (1999). Economics. Moscow: Ed. Binom Knorus, 800.

21. Molchanova N. P., Chernysh E. A. (1999). Prognozirovanie i planirovanie v usloviyakh rynka [Forecasting and planning in market conditions]. M.: PRIOR Publ., 176. (In Russ.)

22. Tretyachenko T. V. (2007). Sotsial'naya infrastruktura munitsipal'nogo obrazovaniya $v$ regional'nom kontekste: sostoyanie, faktory i mekhanizmy rynochnoy transformatsii [Social infrastructure of the municipal formation in the regional context: state, factors and mechanisms of market transformation]. Cand. Sci. thesis, 214. (In Russ.)

23. Ansoff I. (1999). New corporate strategy. Trans. from English. by Ed. Yu.N. Kapturevsky . St. Petersburg: PITER, 401. (In Russ.)

24. Ansoff I., Avner J., Brandenburg R., Portlier F., Radosevich R. (1970). Does Planning Pay? The Effect of Planing on Success of Acquisitions in American Firms. Long-range Planning Journal, 3(2), 2-7.

25. Bagiev G. L., Moiseyeva N. K., Cherenkov V. I. (2008). Mezhdunarodnyy marketing [International Marketing], 2nd ed. St. Petersburg: Peter, 688. (In Russ.)

26. Shevchenko E. V. (2016). Forsayt: metodologiya, praktika issledovaniy [Foresight: methodology, research practice], Omsk: LITERA, 168. (In Russ.)

27. Moldashev A. B. (2008). O prodovol'stvennoy bezopasnosti v respublike Kazakhstan [About food security of the Republic of Kazakhstan], Problemy agrorynka [Problems of the agromarket], 4, 26. (In Russ.)

28. Stukach V. F. (2008). Institutsional'naya struktura regional'nogo agroprodovol'stvennogo rynka [Institutional structure of regional agro-food market], Omsk: Sfera, 224. (In Russ.)

29. Wallis J. (1986). Measuring the Transactional Sector in American Economy, 1870-1970, Long-term factors in American Economic Growth. Chicago, 33-45.

\section{Authors}

Viktor Fedorovich Stukach - Doctor of Economics, Professor, Department of Management and Marketing, Omsk State Agrarian University; ORCID: 0000-0002-2742-6656; Author Scopus ID: 57190431216 (Russian Federation, 644008, Omsk, Institutskaya Sq., 1; e-mail: vic.econ@mail.ru ).

Gulnar Karimovna Saparova - Doctor of Economics, Professor, Financial Academy; ORCID: 0000-0003-34141787; Researcher ID: F- 9679-2018; Author Scopus ID: 57199285790 (Kazakhstan, 010000, Astana, Irchenko, 31; e-mail: saparova_g.k@mail.ru).

Guzel Takhirovna Sultanova - Master of Law, PhD student, Deputy Director of the Department of Legal Support, JSC «National Agency for Technological Development»; ORCID: 0000-0002-4051-604 X; Researcher ID: F- 9697-2018 (Kazakhstan, 010000, Astana, Kartalinskaya, 11, 1; e-mail: guzel1010@mail.ru).

Saniya Azimovna Saginova - PhD Student, Financial Academy; ORCID = 0000-0002-6503-1743; Researcher ID: H2692-2016; Author Scopus ID: 57199296965 (Kazakhstan, 010000, Astana, Saryarka, 8/1; e-mail: saniya.saginova@gmail. com). 